\title{
Application Of Social Web Tools To The Internationalization Of Retail Companies
}

\author{
Alejandro Mollá-Descals, Ph.D., University of Valencia, Spain \\ Miguel-Ángel Gómez-Borja, Ph.D., University of Castilla-La Mancha, Spain \\ Carlota Lorenzo-Romero, Ph.D., University of Castilla-La Mancha, Spain \\ Juan-Antonio Mondéjar-Jiménez, Ph.D., University of Castilla-La Mancha, Spain
}

\begin{abstract}
The emergence and development of what is called the Social Web or Web 2.0 is marked by the appearance and development of new communication tools and applications such as blogs, chats, forums, social networks, etc., and interaction between users. As well as giving consumers emotional and practical benefits, these applications represent great communication opportunities for companies in a globalized context. For this reason, businessmen are increasingly using Social Web tools as instruments to get information and market knowledge, as well as for communication in an internationalization context. Taking the opportunities the use of Social Web tools in a global context represent for retail business as its starting point, this study analyzes the possibilities offered by different tools in the context of the internationalization process of retail distribution businesses, and the uses retailers involved in internationalization processes are currently putting them to. In order to do this, a study is being made by direct observation of the applications and social contents on their web sites, and exploration and monitoring of their presence in other social spaces (blogs, social networks, microblogging, etc.).
\end{abstract}

Keywords: Web 2.0, retail distribution, internationalization, observation

\section{INTRODUCTION}

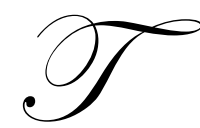

he emergence of the Social Web has been characterized by the appearance and development of new tools allowing users to get information and communicate with each other. These applications give users emotional and practical benefits, and have enormous potential in terms of their use in companies' sales policies and strategies in their relationship with the market.

Direct connection of the retail business with end users allows them to offer them and interact with them through dynamic, personalized web spaces which, as well as informing them, allows them to interact with other users, collect and give opinions, develop individualized products, find sales points by geolocation, join specialized virtual communities, etc.

In addition, most tools and applications produced are developed with a worldwide philosophy, in the sense that they represent interaction platforms which exist in a very similar form in different countries and cultures. Interaction through these spaces and use of these tools gives companies in general and retailers in particular two big advantages. First, the information generated by users in general terms and that generated by the company in particular allows more direct, precise knowledge of consumers and customers and facilitates adaptation to new cultural environments. Secondly, communication generated through these applications is much more direct and specific, also allowing the consumer to be included in the generation process and, when this occurs, adaptation of the product supplied to the, new multicultural environments in which the company works.

\footnotetext{
${ }^{1}$ This study was financed through Research Project reference number ECO2009-08708 (Ministry of Science and Innovation, Government of Spain, 2010-2012).
} 
The analysis carried out in this study will give us information on the social orientation of some retail companies involved in internationalization processes, and will allow reflections on the possibilities and uses of these tools and their future applications.

With this aim, a study is being carried out involving direct observation of the web sites of these companies in terms of use of Web 2.0 applications, as well as monitoring of their presence in different social spaces. The study's results and suggestions contributed are hugely relevant for the retail trade sector, because the interaction of users with the retailer through an attractive, dynamic web site allows a large amount of information about consumers to be obtained, facilitating adaptation to users by means of the same tools and having a positive influence on their possible purchasing, return visits and recommendations to other users.

\section{THE SOCIAL WEB AND RETAIL TRADE}

\section{What is the Social Web?}

So we begin with a new term which has become a fashionable expression: Web 2.0 or the Social Web. The term Web 2.0 was coined in 2005 by Tim O'Reilly (O'Reilly, 2005), who described it as a new form of web collaboration, a platform "taking advantage of the collective intelligence." Various definitions have been proposed based on this idea. Hoegg, Martignoni, Meckel and Stanoevska-Slabeva (2006) define it as "the philosophy of maximizing the collective mutual intelligence and added value of each participant in the formal, dynamic exchange of information creation." Others focus on more social aspects (Beer and Burrows, 2007) or stress technical aspects or applications (Facca and Lanzi, 2004; Anderson, 2007). Finally, Nielsen (2007) proposes four components which incorporate all the characteristics of Web 2.0: a) "Rich" Internet Applications (RIA); b) Virtual communities, social networks and user-generated content; c) mashups (the use of the services of other web sites as a platform for the development or improvement of a particular virtual space and d) Internet advertising and the Social Web.

The Social Web could thus give a new impetus to the business sector in general and retail distribution in particular, in some cases mitigating the negative aspects that could be caused by commercialization of goods and services over the Net. In fact, the effects it has on retail business can be classified in three dimensions (Jain and Ganesh, 2007a): content, collaboration and commercialization (Table 1).

Table 1. Implementation of Web 2.0 in retail business

\begin{tabular}{|c|c|c|}
\hline Content parameters & Collaboration parameters & Commercialization parameters \\
\hline $\begin{array}{l}\text { - User experiences (RIA) } \\
\text { - Dynamic help to the user (P2P) } \\
\text { - Data channels (RSS, ATOM, XML, JS) } \\
\text { - Podcasts/Vodcasts } \\
\text { - Search systems (Web semantics) } \\
\text { - Aggregation mechanisms (mashups) }\end{array}$ & $\begin{array}{l}\text { P2P networks of customers, collective } \\
\text { intelligence (blogs, wikis, discussion } \\
\text { forums, user opinions, tags, etc.) } \\
\text { Collaborative personalization of the } \\
\text { product }\end{array}$ & $\begin{array}{l}\text { - Personalization of the end user's product } \\
\text { - Buying help (e-agent through chats) } \\
\text { - Voice-based buying help (VoIP) } \\
\text { - Purchase comparison (brand comparison } \\
\text { and user recommendations) }\end{array}$ \\
\hline
\end{tabular}

Content parameters are related with tools and techniques which seek to offer the user a better, richer information environment. For example, RIAs (Rich Internet Applications) such as FLEX allow presentation formats of greater quality and a more attractive interface to be offered, improving consumers' experience on the web site. The same occurs with the use of RSS channels, podcasts, videocasts or mashups.

Collaboration parameters refers to applications which allow direct interaction between the business and consumers, as well as active participation between consumers and other agents on the web site, to get information about its goods and services.

Finally, commercialization parameters are related with the functions to provide consumers with support when it comes to choosing products. For example, a buying "wizard" or complementary support service through voice or chat tools. 


\section{Internet and the Social Web and the retailer's internationalization}

Grewal and Levy (2007) stress the importance of the analysis of the impact of Internet on retailers' relationship with consumers, emphasizing especially the new forms of interaction with both the company and other users. They also highlight the fact that in a globalized context, research is necessary to understand the keys to success in internationalization process. In their article about emerging research areas in distribution, the same authors (Grewal and Levy, 2009) repeated that it was necessary to carry out research on the role of Internet and ecommerce in retail distribution.

Grewal, Iyer and Levy (2004) noted that "no other innovation has received as much attention from retailers, manufacturers, consumers and the general public as has been given to online retail sales. In fact, no other kind of competition threatens more to disrupt traditional retail trade than e-commerce."

All the statistics indicate an extraordinary growth in retail sales via Internet in recent years. The estimations of different sources (e-marketer, Forrester Research, red.es, etc.) show that the European online retail market is growing at an annual rate of about $37 \%$, while the more mature online market of the United States is growing at a slower rate (Dellner, 2007, internetretail.com). According to Forrester Research (2007), the number of European online purchases will grow to 174 million, with a net average expenditure of 1,500 Euros. With these figures, European e-commerce could reach 263 billion Euros in 2011, taking into account the sale of travel, clothes, complements and electronic products, all above 10 billion Euros a year.

In this context, according to Forrester Research (2008), the main trends and challenges of virtual retailers are related with Web 2.0 concepts such as collaborative merchandising or comparison shopping. Large, worldwide retailers such as Amazon, Bestbuy, Zappos, etc. base a large part of their success on the inclusion of Social Web tools in their e-commerce spaces.

To assess the impact and potential effects of 2.0 concepts and tools, the conceptual framework of Grewal et al. (2004) can be used as the starting point to analyze the phenomena of retail sales via Internet and, in consequence, its expansion and internationalization to the rest of the world. The question is whether Web 2.0, as the technological and conceptual framework, can stimulate benefits and reduce the limitations to the growth of electronic commerce. While some of these elements which facilitate or limit online sales do not depend on Web 2.0 functionalities, its appearance could have an important effect on them. Table 2 shows these elements proposed by these authors.

Table 2. Elements which facilitate or limit online retail sales

\begin{tabular}{|l|l|}
\hline Elements facilitate online sales & Elements which limit online sales \\
\hline & Lack of product testing \\
Product category & Lack of confidence in the Internet medium \\
Availability of information & Lack of instant response \\
Accessibility to price information & Certain consumer services \\
Newness & Loss of privacy and security \\
Web accessibility & Great economies of scale \\
Convenience & Lack of loyalty \\
& Poor logistics \\
& Lack of experience with Internet \\
& Lack of experience with buying in the store \\
\hline
\end{tabular}

Some of the elements that facilitate online purchasing are strengthened by the appearance of the Web 2.0. Consumers can have access to applications with information of greater quality (e.g. using RIA) or can communicate greater confidence (e.g. opinions of expert users), the information can be processed and edited more easily (e.g. buyers and information aggregators). At the same time, online stores have developed additional tools and resources to offer a better buying experience and integrate the consumer himself in the configuration and adaptation of the offer to his tastes and needs. 
In addition, Web 2.0 tools can reduce the risks and uncertainty of buying online. Its main advantage is the new, interactive, social dimension which characterizes it. This interaction, both with the staff of the online retail sales point and with other consumers, can increase confidence (e.g. electronic agents and virtual communities) and improve customer service (e.g. chats or VoIP applications).

\section{METHODOLOGY: CURRENT STATUS OF THE STUDY}

At the moment, the field work is being carried out through a study involving observation of the web spaces of retail distribution companies, analysing the use these companies make of Web 2.0 applications (podcasts, RSS, mashups, RIA, P2P, wikis, product personalization, etc.), and monitoring their presence in different social spaces (blogs, social networks, microblogging, etc.). For this purpose, analysis of the content of different Web 2.0 tools on each web site, the place where the tools are positioned within each site, and the accessibility they offer to the user, among other things, is being carried out. The sample chosen comes from the SABI database, using the retail distribution sector provided by that database as first discrimination filter, deaggregating the sector by sectors, and as the second filter, identifying those which use e-commerce as a means of internationalization by web observation of their sales strategy.

\section{CONCLUSIONS AND FUTURE CONTRIBUTIONS}

As has been shown, Web 2.0 functionalities applied to the retail trade sector have notable potential for achieving increased demand, internationalization over the Net. Improvement in both the overall value of the company (through strengthening physical interactions and online retail sales via e-commerce) and of its specific benefits (reaching and keeping customers) can be achieved by the combination of different 2.0 tools. So the creation of a dynamic, interactive atmosphere at the retail point of sale becomes an increasingly competitive element, and future success and survival will to a large extent depend on retailers who understand and focus their sales strategy on satisfying ever more demanding, sophisticated, interactive and social future consumers. We think the results and suggestions provided by the study we obtain in the end could be relevant to the sector of retail business which is internationalizing over the Net, because a user's visit to an attractive, interactive, Social Web site has a positive effect on the possibility of making a purchase, making a return visit and recommending that online store to other people.

\section{AUTHOR INFORMATION}

Alejandro Mollá-Descals: Degree in Economics and Business and $\mathrm{PhD}$ from University of Valencia (Spain). Currently Professor in Marketing at Marketing Department. Faculty of Economics, University of Valencia (Spain). E-mail: Alejandro.Molla@uv.es Research Interest: Retailing, Internationalization, consumer behavior and marketing research.

Miguel-Ángel Gómez-Borja: Degree in Economics and Business from University of Valencia (Spain). and PhD on E-Marketing from University of Castilla-La Mancha (Spain). Currently Associate Professor in Marketing at Business Administration Department. Faculty of Economics and Business Administration of Albacete, University of Castilla-La Mancha (Spain). E-mail: MiguelAngel.GBorja@uclm.es

Research Interest: Electronic commerce, Web 2.0, Social Networking consumer behaviour, marketing research, experimental designs, and quantitative analysis.

Carlota Lorenzo-Romero: Degree in Business Administration and $\mathrm{PhD}$ on E-Marketing from University of Castilla-La Mancha (Spain). Currently Assistant Professor in Marketing at Business Administration Department. Faculty of Economics and Business Administration of Albacete, University of Castilla-La Mancha (Spain). E-mail: Carlota.Lorenzo@uclm.es

Research Interest: Electronic commerce, Web 2.0, Social Networking Sites, store atmosphere, e-merchandising, consumer behaviour, marketing research, experimental designs, and quantitative analysis.

Juan-Antonio Mondéjar-Jiménez: $\mathrm{PhD}$ and Degree in Business Administration by University of Castilla-La Mancha. Degree in Advanced Studies in Marketing at the same university. Associate Professor in Marketing at 
Business Department. Faculty of Social Sciences of Cuenca. University of Castilla-La Mancha (Spain). E-mail: JuanAntonio.Mondejar@uclm.es

Research Interest: Consumer behavior, price perception, electronic commerce, e-learning and tourism marketing.

\section{REFERENCES}

1. Anderson, P. (2007). "What is Web 2.0? Ideas, technologies and implications for education", JISC Technology and Standards Watch, Feb, pgs. 1-64.

2. Arroyo (2007). “¿Web 2.0? ¿web social? ¿qué es eso?”, Educación y biblioteca, no 161, pgs. 69-74.

3. Beer, D. Y Burrows R. (2007). "Sociology and, of and in Web 2.0: some initial considerations", Sociological Research, Vol. 12, $\mathrm{n}^{\circ}$ 5, http://www.socresonline.org.uk/12/5/17.html.

4. Bughin, J. (2008). "The rise of enterprise 2.0”, Journal of Direct, Data and Digital Marketing Practice, Vol. 9, nº 3, pgs. 251-259.

5. $\quad$ Dellner, T. (2007). "European e-commerce”, Electronic Retailer Magazine, Junio, www.electronicretailmag.com.

6. $\quad$ Facca, F.M. Y Lanzi, P.L. (2004). "Mining interesting knowledge from weblogs: a survey", Data and Knowledge Engineering, Vol. 53, n 3, pgs. 225-241.

7. Forrester Research (2007). Marketing on social networking sites, Charlene Li, Josh Bernoff, Katheryn A. Feffer, Cynthia N. Pflaum, http://www.forrester.com/Research/Document/Excerpt/0,7211,41662,00.html.

8. $\quad$ Forrester Research (2008). Trends 2008: European eCommerce and Online Retail, Victoria Braceweel, Michelle de Lussanet y Lauriane Camus, http://www.forrester.com/Research/Document/Excerpt/0,7211,44528,00.html.

9. Grewal, D.; Iyer, G.R. Y Levy, M. (2004). ““'Internet retailing: enablers, limiters and market consequences", Journal of Business Research, Vol. 57, nª 7, pgs. 703-713.

10. Hitwise (2007). US research note: Measuring Web 2.0 consumer participation.

11. Hoegg, R.; Martignoni, R.; Meckel, M. Y Stanoevska-Slabeva, K. (2006). "Overview of business models for Web 2.0 communities". Actas del Congreso internacional GeNeMe 2006, Dresden, Alemania. http://www.alexandria.unisg.ch/Publikationen/31411

12. Jain, A. Y Ganesh, J. (2007A). Harnessing the Power of Web 2.0 in Online Retail. Part I: An overview of Web 2.0 adoption in Retail. White paper. Infosys, www.infosys.com.

13. Jain, A. Y Ganesh, J. (2007B). Harnessing the Power of Web 2.0 in Online Retail. Part II: An Implementation Roadmap for Retailers. White paper. Infosys, www.infosys.com.

14. Nielsen, J. (2007). “Web 2.0 can be dangerous...”, Jakob Nielsen's Alertbox, Diciembre 17, http://www.useit.com/alertbox/web-2.html

15. O'Reilly, T. (2005). What is Web 2.0. Design patterns and business models for the next generation of software. http://www.oreillynet.com/pub/a/oreilly/tim/news/2005/09/30/what-is-web-20.html. 
NOTES 